\title{
Polyhydroxyalkanoate biosynthesis by oxalotrophic bacteria from high Andean soil
}

\author{
Roger David Castillo Arteaga, ${ }^{1, *}$ Edith Mariela Burbano Rosero, \\ Iván Darío Otero Ramírez, Juan Camilo Roncallo, Sandra Patricia Hidalgo \\ Bonilla $^{4}$ and Pablo Fernández Izquierdo ${ }^{2}$
}

Edited by

Juan Carlos Salcedo-Reyes

(salcedo.juan@javeriana.edu.co)

1. Universidade de São Paulo,

Instituto de Ciências Biomédicas,

Laboratório de Bioprodutos,

Av. Prof. Lineu Prestes, 1374, São Paulo,

SP, Brasil, CEP 05508-900.

2. Universidad de Nariño,

Departamento de Biología.

Grupo de Investigación de Biotecnología

Microbiana. Torobajo, Cl 18 - Cra 50.

San Juan de Pasto, Colombia.

3. Universidad del Cauca,

Facultad de Ciencias Agrarias,

Grupo de Investigación en

Aprovechamiento de Subproductos

Agroindustriales, $\mathrm{Cl} 5$ No. 4 - 70,

Popayán, Colombia.

4. Universidad de Investigación de

Tecnología Experimental,

Yachay Tech, Escuela de Ciencias

Químicas e Ingeniería.

San Miguel de Urcuquí, Ecuador.

*rogerdavyd@usp.br

Received: 03-03-2017

Accepted: 01-06-2018

Published on line: 02-16-2018

Citation: Castillo Arteaga RD, Burbano Rosero EM, Otero Ramirez ID, Roncallo JC, Hidalgo Bonilla SP, Fernández Izquierdo P. Polyhydroxyalkanoate biosynthesis by oxalotrophic bacteria from high Andean soil, Universitas Scientiarum, 23 (1): 35-59, 2018. doi: 10.11144/Javeriana.SC23-1.pbbo

Funding: N.A.

Electronic supplementary material: N.A.

OPEN ACCESS

\begin{abstract}
Oxalate is a highly oxidized organic acid anion used as a carbon and energy source by oxalotrophic bacteria. Oxalogenic plants convert atmospheric $\mathrm{CO}_{2}$ into oxalic acid and oxalic salts. Oxalate-salt formation acts as a carbon sink in terrestrial ecosystems via the oxalate-carbonate pathway (OCP). Oxalotrophic bacteria might be implicated in other carbon-storage processes, including the synthesis of polyhydroxyalkanoates (PHAs). More recently, a variety of bacteria from the Andean region of Colombia in Nariño have been reported for their PHA-producing abilities. These species can degrade oxalate and participate in the oxalate-carbonate pathway. The aim of this study was to isolate and characterize oxalotrophic bacteria with the capacity to accumulate PHA biopolymers. Plants of the genus Oxalis were collected and bacteria were isolated from the soil adhering to the roots. The isolated bacterial strains were characterized using biochemical and molecular biological methods. The consumption of oxalate in culture was quantified, and PHA production was monitored in batch fermentation. The polymeric composition was characterized using gas chromatography. Finally, a biosynthetic pathway based on our findings and on those from published sources is proposed. Strains of Bacillus spp. and Serratia sp. were found to metabolize calcium oxalate and synthesize PHA.
\end{abstract}

Keywords: oxalotrophic bacteria; polyhydroxyalkanoates; 16S rRNA gene; gas chromatography; biosynthetic pathway in silico

\section{Introduction}

In plants, the disequilibrium of the terrestrial carbon cycle (excess $\mathrm{CO}_{2}$ ) causes biological alterations such as increased biomass and increased production of carboxylic acids. These carboxylic acids are secreted through the roots, as a detoxification system, to the soil [1-4]. Oxalic acid and its calcium salt, which 
contain dicarboxylate ions, are widely distributed in animals, plants, and fungi and other microorganisms [5]. The accumulation of calcium oxalate has been reported in more than 215 families of angiosperms and gymnosperms, and occurs in approximately 1000 genera [6], including the Oxalidaceae family [6-11].

The oxalate-carbonate pathway (OCP) is a biogeochemical natural process for trapping atmospheric carbon and includes interactions between plants and microorganisms [12]. Many taxonomic groups of bacteria can use oxalate as a sole carbon source via the degradation of calcium oxalate. Consequently, this degradation leads to the precipitation of $\mathrm{CaCO}_{3}[13]$. Oxalotrophy is widespread and is exhibited by gram-negative (Alpha-, Beta- and Gammaproteobacteria) and gram-positive bacteria (Firmicutes and Actinobacteria). The role of oxalotrophic bacteria as major calcium oxalate oxidizers was recently demonstrated [12]. Conventional culture methods reveal a diverse assemblage of oxalotrophic bacteria living near the rhizospheres of Terminalia oblonga, Terminalia bellirica, and Milicia excelsa in tropical forests of Bolivia, India, and Cameroon, respectively [14]. In the intertropical zone, the OCP observed underneath certain tropical trees like iroko (Milicia excelsa) is surprisingly well developed. By photosynthesis, the trees accumulate large quantities of organic salts, mainly in the form of calcium oxalate, which is a sparingly soluble salt (solubility product constant (Ksp) of $1.6 \times 10^{-9}$ at $25^{\circ} \mathrm{C}$ for the monohydrate), forming crystals in the plant tissues. The thermodynamic solubility product of calcium oxalate monohydrate $(\mathrm{COM})$ at $25^{\circ} \mathrm{C}$ is $1.6 \times 10^{-9}$, that of calcium oxalate dihydrate $(\mathrm{COD})$ is $3.7 \times 10^{-9}$ and that of calcium oxalate trihydrate (COT) is $5.0 \times 10^{-9}$. These values are associated with relative solubility, which indicates that the solubility of calcium oxalate hydrates decreases in the order $\mathrm{COM}>\mathrm{COD}>\mathrm{COT}[15,16]$.

Calcium oxalate is consumed by bacteria present in the soil, which convert calcium oxalate to calcium carbonate via a biomineralization process in combination with other factors $(\mathrm{pH}$, transformation of oxalate into bicarbonate, and equilibrium reactions and constants governing the dissolution of $\mathrm{CO}_{2}$ in aqueous media $\left(\mathrm{CO}_{3}{ }^{2-}, \mathrm{HCO}_{3}-\right.$, and $\left.\left.\mathrm{H}_{2} \mathrm{CO}_{3}\right)\right)$ [17-19] (fig. 1). This phenomenon is a n et carbon $t$ rap in which the i nitial $\mathrm{CO}_{2}$ is atmospheric. The mainly acidic, non-calcareous soils found in tropical countries represent a significant sink for atmospheric $\mathrm{CO}_{2}$ : at the present rate of increase, one full-grown iroko tree may stabilize the concentration of $\mathrm{CO}_{2}$ in the air column over a $2400 \mathrm{~m}^{2}$ surface $[9,14]$. 


$$
\begin{array}{ll}
\mathrm{Ca}(\mathrm{COO})_{2} \rightleftharpoons \mathrm{Ca}^{2+}+(\mathrm{COO})_{2}{ }^{2-} & \begin{array}{l}
(\text { Ca-oxalate dissolution-weathering }) \\
(\mathrm{COO})_{2}{ }^{2-}+1 / 2 \mathrm{O}_{2}+\mathrm{H}_{2} \mathrm{O} \rightarrow 2 \mathrm{CO}_{2}+2 \mathrm{OH}-
\end{array} \\
\mathrm{Ca}^{2+}+\mathrm{CO}_{2}+2 \mathrm{OH}-\rightarrow \mathrm{CaCO}_{3}+\mathrm{H}_{2} \mathrm{O} & \begin{array}{l}
\text { (Oxalate catabolism via aerobic } \\
\text { respiran })
\end{array} \\
\mathrm{Ca}(\mathrm{COO})_{2}+1 / 2 \mathrm{O}_{2} \rightarrow \mathrm{CaCO}_{3}+\mathrm{CO}_{2} & \text { (ovecipitation) }
\end{array}
$$

Figure 1. The overall equations for Ca-carbonate formation from Ca-oxalate [17].

These circumstances make the rhizosphere (not a region of definable size or shape, but instead, a gradient of chemical, biological and physical properties that change both radially and longitudinally along the root) a competitive environment where microorganisms must develop strategies and mechanisms to improve their establishment, proliferation, and survival. The accumulation of polyhydroxyalkanoates (PHAs) has been proposed as being one such strategy. This is because the accumulation and subsequent degradation of these compounds is used for carbon and energy storage, and these compounds are mainly synthesized in chains of four carbons (polyhydroxybutyrate - PHB) from a wide range of organic substances in conditions of carbon imbalance, compared to nitrogen or phosphorus [20-23]. Several investigations have reported that a high concentration of oxalate in the rhizosphere is metabolized via two known pathways that diverge as the glycolate pathway and a variant of the serine pathway to produce 3-P-glycerate [5], which subsequently produces acetyl-CoA, a metabolic molecule that yields PHA [22]. However, to our knowledge, no research has been focused on the study of this type of bacteria in the application of this metabolism in soil.

In this study, we screened the production of PHA in oxalotrophic bacterial isolates from the soil adhering to the root of plant species from the genus Oxalis growing in the high Andean zone of Colombia. The positive strains were identified by partial sequencing of the $16 \mathrm{~S}$ rRNA gene. Additionally, we discuss the results of gas chromatography analysis for the biopolymeric synthesis. 


\section{Materials and methods}

\section{Description of sampling sites}

In Colombia, the species O. spiralis and O. tuberosa are found at 2700 and $3800 \mathrm{~m}$ above sea level along the central and southern Andes, respectively. Considering this distribution, the plants were collected by taking into account the presence of seeds and the state of maturation of the individual [23]. The local temperature was between $12{ }^{\circ} \mathrm{C}$ and $18{ }^{\circ} \mathrm{C}$, and the precipitation was between $1000 \mathrm{~mm}$ and $4000 \mathrm{~mm}$ per year. The samples (plant and soil near the roots) were labelled and transported to the PSO herbarium of the University of Nariño to be dried and identified. The selected soil was used in previous studies, and the physicochemical parameters of this soil have been characterized extensively [24]. The geographical locations of sampling are given in Table 1.

\section{Isolation of carbon-storing oxalotrophic bacteria}

Enrichment was performed in Schlegel AB liquid medium [25] modified for the isolation of oxalotrophic bacteria with $16 \mathrm{~g} / \mathrm{L}$ of insoluble calcium oxalate monohydrate, $\mathrm{Ca}(\mathrm{COO})_{2} \cdot \mathrm{H}_{2} \mathrm{O}$, as the sole carbon source (good energy efficiency [26]). The culture medium was adjusted to $\mathrm{pH} 7.0$ and autoclaved for two hours. Ninety millilitres of medium in $250-\mathrm{mL}$ flasks were inoculated with $10 \mathrm{~g}$ of dried soil and incubated at $30^{\circ} \mathrm{C}$ with constant shaking at $100 \mathrm{rpm}$ for 12 hours. Serial dilutions up to $10^{-7}$ were prepared and $0.1 \mathrm{~mL}$ of the dilutions was spread on solid Schlegel $A B$ medium with calcium oxalate. Fluorescence of the Nile red dye ( $0.01 \%$, Sigma-Aldrich, USA) was measured as an indicator of PHA [27]. The plates were incubated at $30^{\circ} \mathrm{C}$ for two weeks following the conditions proposed by Sahin and collaborators [28]. The bacterial colonies showing clear halos and fluorescence in Schlegel medium were considered positive for oxalate degradation and PHA lipid accumulation, respectively $[29,30-32]$.

\section{Oxalate consumption by oxalotrophic bacteria}

Oxalate consumption by the bacteria was determined by the methodology proposed by Blackmore and Quayle [33]. Each bacterial isolate was inoculated into $250-\mathrm{mL}$ flasks containing $60 \mathrm{~mL}$ of Schlegel culture broth adjusted to $\mathrm{pH}$ 5.0, at which the plant and the soil adhering to the root were collected. Cell suspensions were incubated at $30^{\circ} \mathrm{C}$ with constant shaking at $100 \mathrm{rpm}$. Every 24 hours the $\mathrm{pH}$ was measured, and the medium resulted, in general, slightly acidic [24]. 
Table 1. Oxalogenic plants and characteristics of samples.

\begin{tabular}{cccc}
\hline $\begin{array}{c}\text { Oxalogenic } \\
\text { plant }\end{array}$ & $\begin{array}{c}\text { Altitude } \\
\text { (meters above } \\
\text { sea level) }\end{array}$ & Geographical location (coordinates) & $\begin{array}{c}\text { Type } \\
\text { of soil }\end{array}$ \\
\hline $\begin{array}{c}\text { Oxalis } \\
\text { tuberosa }\end{array}$ & $3090 \mathrm{~m}$ & $1^{\circ} 08^{\prime} 0.371^{\prime \prime} \mathrm{N} ; 77^{\circ} 18^{\prime} 22.05^{\prime \prime} \mathrm{W}$ & Andisol \\
$\begin{array}{c}\text { Oxalis } \\
\text { spiralis }\end{array}$ & $3144 \mathrm{~m}$ & $1^{\circ} 03^{\prime} 02.05^{\prime \prime} \mathrm{N} ; 77^{\circ} 41^{\prime} 02.86^{\prime} \mathrm{W}$ & Andisol \\
\hline
\end{tabular}

The oxalate concentration of the medium after the incubation period was then determined by titration with $0.1 \mathrm{~N}$ standard sodium permanganate $\left(\mathrm{KMnO}_{4}\right)$. Three millilitres of culture medium were extracted, and the calcium oxalate was solubilized by the addition of $1 \mathrm{~mL}$ of $2 \mathrm{~N}$ sulfuric acid $\left(\mathrm{H}_{2} \mathrm{SO}_{4}\right)$ and titrated at $60^{\circ} \mathrm{C}$ until a pink colour persisted for $30 \mathrm{~s}$. Oxalate concentrations in the media (consumption) were calculated from the stoichiometry of reactants and products [33].

\section{Evaluation of polyhydroxyalkanoate synthesis by bacterial isolates}

The selected isolates were subjected to batch-type fermentation to produce PHA in liquid mineral medium (MM). The mineral medium, adapted from Rocha et al. [34], contained the following components (per litre): $1.5 \mathrm{~g}$ of $\mathrm{KH}_{2} \mathrm{PO}_{4} ; 3.54 \mathrm{~g}$ of $\mathrm{Na}_{2} \mathrm{HPO}_{4} ; 1.0 \mathrm{~g}$ of $\left(\mathrm{NH}_{4}\right)_{2} \mathrm{SO}_{4} ; 0.2 \mathrm{~g}$ of $\mathrm{MgSO}_{4} \cdot 7 \mathrm{H}_{2} \mathrm{O}$; $0.01 \mathrm{~g}$ of $\mathrm{CaCl}_{2} \cdot 2 \mathrm{H}_{2} \mathrm{O} ; 0.06 \mathrm{~g}$ of $\left(\mathrm{NH}_{4}\right)_{5}\left[\mathrm{Fe}\left(\mathrm{C}_{6} \mathrm{H}_{4} \mathrm{O}_{7}\right)_{2}\right] \cdot 2 \mathrm{H}_{2} \mathrm{O}$ and $1.0 \mathrm{~mL}$ of trace elements solution. The trace elements solution contained the following components $(\mathrm{g} / \mathrm{L}): \mathrm{H}_{3} \mathrm{BO}_{3}, 0.30 ; \mathrm{CoCl}_{2} \cdot 6 \mathrm{H}_{2} \mathrm{O}, 0.20 ; \mathrm{ZnSO}_{4} \cdot 7 \mathrm{H}_{2} \mathrm{O}$, $0.1 ; \mathrm{MnCl}_{2} \cdot 4 \mathrm{H}_{2} \mathrm{O}, 0.03 ; \mathrm{NaMoO}_{4} \cdot 2 \mathrm{H}_{2} \mathrm{O}, 0.03 ; \mathrm{NiCl}_{2} \cdot 6 \mathrm{H}_{2} \mathrm{O}, 0.02$ and $\mathrm{CuSO}_{4} \cdot 5 \mathrm{H}_{2} \mathrm{O}, 0.01$ [34]. The medium was supplemented with calcium oxalate as the sole carbon source; the source $\mathrm{N}: \mathrm{C}$ ratio was 1:4. The fermentation experiments were conducted in triplicate for each bacterial isolate over 144 hours at $30{ }^{\circ} \mathrm{C}$ and $100 \mathrm{rpm}$. Then, $10 \mathrm{~mL}$ of a sample was centrifuged at $8000 \mathrm{rpm}$ for 10 minutes. The pellet was resuspended in $1 \mathrm{~mL}$ of $5 \%$ sodium hypochlorite and $10 \mathrm{mM}$ EDTA. The suspension was incubated for 75 minutes at $60^{\circ} \mathrm{C}$, centrifuged at $8000 \mathrm{rpm}$ for 5 minutes, and washed repeatedly with $1 \mathrm{~mL}$ of distilled water, $1 \mathrm{~mL}$ of acetone and $1 \mathrm{~mL}$ of cold methanol; after each step, the sample was centrifuged at $8000 \mathrm{rpm}$ for 5 minutes [26, 51]. Finally, the polymer was dried and weighed [35]. The values were reported as the means and the standard deviation $( \pm \mathrm{SD})$ was calculated. 
Characterization of the polymer by gas chromatography (GC)

The obtained polymer was dissolved in $1 \mathrm{~mL}$ of chloroform (HPLC grade) and $1 \mathrm{~mL}$ of derivatizing reagent (methanol/sulfuric acid; 85:15 v/v), and the reaction was performed at $90^{\circ} \mathrm{C}$ for two hours. The mixture was cooled rapidly, and $1 \mathrm{~mL}$ of saline solution $(0.1 \% \mathrm{NaCl})$ was added. Finally, the aqueous phase was removed, and the organic phase was treated with pure anhydrous sodium sulphate to remove any remaining water [36].

The gas chromatography (GC) analysis was carried out in the University of Nariño laboratories in a Shimadzu GC-17A gas chromatograph equipped with a flame ionization detector (FID); helium AP was used as a carrier gas, and a capillary column of fused silica MDN-5 was used, which was $30 \mathrm{~m}$ in length, $0.25 \mathrm{~mm}$ in internal diameter and 0.25 microns in film thickness (Supelco). The injector and detector temperatures were set to an ionizing flame at $250{ }^{\circ} \mathrm{C}$. The temperature program was $60^{\circ} \mathrm{C}$ for 2 minutes, increasing $6^{\circ} \mathrm{C}$ per minute to a maximum temperature of $220^{\circ} \mathrm{C}[35,36]$. The reference standard used was the copolymer poly-3-hydroxybutyrate-co-3-hydroxyvalerate.

Biochemical characterization of oxalotrophic bacteria producing neutral lipids.

Biochemical characterization was conducted as per Bergey's manual [37]. These tests included the following: motility test, indole test, sulphide test, catalase activity test, oxidase activity test, the Voges-Proskauer test, and Simmons' citrate test. The temperatures of incubation were $20^{\circ} \mathrm{C}, 40{ }^{\circ} \mathrm{C}$ and $65{ }^{\circ} \mathrm{C}$. The $\mathrm{NaCl}$ concentrations used were $2 \%, 4 \%, 7 \%$, and $10 \%$, and the $\mathrm{pH}$ values used were 4.0, 5.7, and 6.8. The fermentation process used glucose, sucrose, fructose, maltose, galactose, xylose, rhamnose, lactose, mannose, arabinose, and ribose [35].

\section{DNA extraction}

For DNA extraction, a protocol by Rivera and collaborators [38] was used with some modifications. Initially, bacterial isolates were inoculated into $25 \mathrm{~mL}$ of Luria-Bertani broth (LB) and incubated at $30^{\circ} \mathrm{C}$ for 24 hours or until an approximate concentration of $10^{8} \mathrm{CFU} . \mathrm{mL}^{-1}$ was reached. Subsequently, the cells were centrifuged at $7800 \mathrm{rpm}$ for 10 minutes; the cell pellet was dissolved in $2.4 \mathrm{~mL}$ of TE buffer $(1 \mathrm{M})$ and then homogenized by vortexing for 5 seconds. Then, $62.5 \mu \mathrm{L}$ of SDS $10 \%$ and $6.25 \mu \mathrm{L}$ of proteinase $\mathrm{K}(20 \mathrm{mg} / \mathrm{mL})$ were added to each tube prior to gentle homogenization. The mix was incubated in a water bath at $37^{\circ} \mathrm{C}$ for 1 hour [38]. 
Subsequently, $300 \mu \mathrm{L}$ of $5 \mathrm{M} \mathrm{NaCl}$ and $188 \mu \mathrm{L}$ of CTAB (10\%) were added. The solution was stirred in a water bath at $65^{\circ} \mathrm{C}$ for 20 minutes. Then, an equal volume of chloroform:isoamyl alcohol (24:1) was added, and the solution was centrifuged at $8000 \mathrm{rpm}$ for 20 minutes. The supernatant was transferred to another tube and $3 \mu \mathrm{L}$ of RNase $(10 \mathrm{mg} / \mathrm{mL})$ was added; the tube was incubated for 1 hour at $37^{\circ} \mathrm{C}$. Then, an equal volume of chloroform was added, and the mixture was homogenized, vortexed and centrifuged at $8000 \mathrm{rpm}$ for 15 minutes. The supernatant was transferred to another tube, and DNA was precipitated with $0.6 \mathrm{~mL}$ of isopropanol. The mix was centrifuged again at $8000 \mathrm{rpm}$ for 20 minutes, the pellet was washed with $100 \mathrm{~mL}$ of ethanol and finally centrifuged at $9000 \mathrm{rpm}$ for 5 minutes. The supernatant was discarded and the DNA was dried overnight at room temperature. The DNA was resuspended in TE $(1 \mathrm{M})$ and stored at $4{ }^{\circ} \mathrm{C}$ for subsequent use. [35]

\section{Quantification of DNA}

The quality of the extracted DNA was checked on a $1 \%$ agarose gel run in a Fisher electrophoresis chamber at 60 volts for two hours. The molecular marker used was Lambda Hind III (Promega). The DNA was obtained by measuring the absorbance at $260 \mathrm{~nm}$ and $280 \mathrm{~nm}$ using a Genova Jenway spectrophotometer. Additionally, the A260/A280 ratios were calculated using the extinction coefficient for double stranded DNA (dsDNA), $0.0208(\mu \mathrm{g} / \mathrm{ml})^{-1} \mathrm{~cm}^{-1}$, and assuming that $1 \mathrm{OD}$ at $260 \mathrm{~nm}$ equals $50 \mu \mathrm{g} / \mathrm{mL}$ DNA [39].

\section{Amplification of the $16 \mathrm{~S}$ rRNA gene}

For the 16S rRNA gene amplification, universal primers 27F [AGAGTTTGATCMTGGCTCAG] [40].

And 1041R [CGGTGTGTACAAGACCC] [41] were used; the primers were synthesized by Integrated DNA Technologies.

The Polymerase Chain Reaction (PCR) was performed in a final volume of $50 \mu \mathrm{L}$. The master mix consisted of $10 \mu \mathrm{L}$ of Green GoTaq ${ }^{\circledR} 5 \mathrm{X}$ buffer (Promega), $1 \mu \mathrm{L}$ of $2.5 \mathrm{mM} \mathrm{MgCl}_{2}$ (Promega), $1 \mu \mathrm{L}$ of a $2.5 \mathrm{mM}$ dNTP mix, $1 \mu \mathrm{L}$ of each primer $(27 \mathrm{~F}$ and $1041 \mathrm{R})$ at a final concentration of $20 \mu \mathrm{M}, 0.4 \mu \mathrm{L}$ of DNA Polymerase GoTaq ${ }^{\circledR}$ (Promega) $(5 \mathrm{U} / \mu \mathrm{L})$ and $2 \mu \mathrm{L}$ of $100 \mathrm{ng} / \mu \mathrm{L}$ DNA target.

Amplification cycles were as follows: 2 minutes at $95{ }^{\circ} \mathrm{C}$ for initial denaturation followed by 30 cycles of $94^{\circ} \mathrm{C}$ for 3 minutes, $5^{\circ} \mathrm{C}$ for 1 minute, 
and $74{ }^{\circ} \mathrm{C}$ for 3 minutes, and a final elongation at $72{ }^{\circ} \mathrm{C}$ for 10 minutes. All reactions were performed in a thermocycler (MultiGene) in 0.2-mL Eppendorf tubes.

The DNA fragments amplified by PCR were visualized by agarose gel electrophoresis; the gel was run in $1 \mathrm{X}$ TBE buffer for 2 hours at $70 \mathrm{~V}$ and stained with $1 \%$ ethidium bromide $(0.5 \mu \mathrm{g} / \mathrm{mL})$. A $1-\mathrm{Kb}$ molecular size marker was used (Promega). The amplified DNA fragments were visualized under UV light, and images were observed with a Gel Doc XR+ System controlled by Image Lab ${ }^{\mathrm{TM}}$ software (Bio-Rad).

Amplicons were sent to Macrogen (Korea) for sequencing. Sequencing was performed using the method of Sanger et al. [42] using BigDye ABI3730XL with capillary electrophoresis. Using the ClustalW program and BLAST, the partial sequences of the $16 \mathrm{~S}$ rRNA genes of the characterized wild bacterial isolates were aligned with further downstream nucleotide sequences obtained from the GenBank/Ribosomal Database Project/NCBI databases.

The 16S rRNA partial sequences were compared with the sequences available at the Ribosomal Database Project (RDP - http://rdp.cme.msu.edu/) [43] using the classifier tool to assign sequences to taxonomic levels. The Sequence Match tool was used to assign one representative of each cluster to the closest type-strain neighbour. Additionally, the same sequences were compared with 16S rRNA sequences deposited in the database of the National Centre for Biotechnology Information (NCBI GenBank) using the BLASTn tool.

\section{Results}

\section{Identification and analysis of oxalotrophic strains}

A total of 346 colonies with clear halos were obtained; no fungal microbiota was observed. Thirty oxalotrophic strains were isolated; colonies showing dissolution halos were selected as positive, and slants were prepared in fresh medium. Seven of the slants showed growth and fluorescence in Schlegel $\mathrm{AB}$ supplemented with calcium oxalate. This observation made possible the evaluation of the stained colonies that fluoresced under UV light. The isolates grew over 12 days, and all the isolates showed degradation halos around the colonies. The fluorescence was clear only on the fifteenth day. Six isolates were gram-positive and one was gram-negative. The selected colonies were transferred to plate count agar medium with Nile red and glucose. This medium had a greater imbalance in the carbon/nitrogen ratio; this imbalance was necessary for lipid accumulation $[21,31]$. 
The ideal growth temperatures were $30^{\circ} \mathrm{C}$ to $42^{\circ} \mathrm{C}$. The ideal growth medium containing $4 \%$ and $7 \%$ of $\mathrm{NaCl}$ was used to test growth in the presence of different carbohydrates (Table 2).

The fluorescent oxalotrophic strains were identified based on their 16S rRNA gene sequences. SeqMatch (Ribosomal Database Project) and BLAST (NCBI) were used to compare and classify the sequences. Six strains were identified as Bacillus and one as Serratia. A complete description of the identified strains is presented in Table 2.

\section{Production of PHA}

Regarding the production of PHA, it was observed that of the seven oxalotrophic bacteria, the isolates OS2, OS3, OT2 and OT3 showed high accumulation of the biopolymer at 96 h; i.e., $233 \mathrm{mg} / \mathrm{L}, 167 \mathrm{mg} / \mathrm{L}, 33 \mathrm{mg} / \mathrm{L}$ and $100 \mathrm{mg} / \mathrm{L}$, respectively. The isolate OT1 showed high accumulation at $120 \mathrm{~h}(149 \mathrm{mg} / \mathrm{L})$. Isolates OS1 and OS4 had the highest production of the biopolymer at 144 hours: $126 \mathrm{mg} / \mathrm{L}$ and $118 \mathrm{mg} / \mathrm{L}$, respectively (Table 3).

\section{Detection of PHA by gas chromatography}

Gas chromatography (GC) was employed to perform monomer identification. The retention times of the methylated monomers of PHA synthesized by the isolate were identified by comparing the sample retention times with the retention times of the commercially available copolymer of ethyl 3-hydroxybutyrate and methyl 3-hydroxyvalerate $(3 \mathrm{HB}-\mathrm{co}-3 \mathrm{HV})$ as standards; the methylated derivatives of the commercial copolymer formed two peaks with retention times of 4.5 minutes and 6.4 minutes. The strains OS1, OS2, OS3, OS4, OT1, OT2 and OT3 synthesized the monomer poly-3-hydroxybutyrate.

\section{Discussion}

Plant exudates containing oxalic acid provide an abundant source of carbon and nitrogen which are used by microorganisms in the rhizosphere, leading to an increase in the organic-matter content of the soil. Interestingly, a large fraction of the oxalotrophic bacterial isolates from Africa and Latin America correspond to the rhizospheric bacteria that may play a role in long-term soil pedogenic processes such as the OCP $[14,44,45]$. 
Table 2. Identification and biochemical characterization of the identified strains.

\begin{tabular}{|c|c|c|c|c|c|c|c|}
\hline Strain & OS1 & OS2 & OS3 & OS4 & OT1 & OT2 & OT3 \\
\hline Species & Serratia fonticola & $\begin{array}{l}\text { Bacillus } \\
\text { subtilis }\end{array}$ & $\begin{array}{l}\text { Bacillus } \\
\text { subtilis }\end{array}$ & $\begin{array}{c}\text { Bacillus } \\
\text { vallismortis }\end{array}$ & $\begin{array}{c}\text { Bacillus } \\
\text { vallismortis }\end{array}$ & $\begin{array}{l}\text { Bacillus } \\
\text { amyloliquefaciens }\end{array}$ & Bacillus cereus \\
\hline ID $\%$ & 99 & 99 & 100 & 98 & 97 & 98 & 98 \\
\hline Accession code & $\begin{array}{c}\text { KF0548381 } \\
\text { GI:514251462 }\end{array}$ & S000843647 & S000843647 & S000012241 & S000012241 & S000356609 & S000038676 \\
\hline $\begin{array}{c}\text { UV } \\
\text { Fluorescence } \\
\text { (Nile red) }\end{array}$ & Pink & Orange & Orange & Orange & Orange & Orange & Orange \\
\hline Gram staining & - & + & + & + & + & + & + \\
\hline Growth $20^{\circ} \mathrm{C}$ & + & - & + & + & + & + & + \\
\hline Growth $30^{\circ} \mathrm{C}$ & + & + & + & + & + & + & + \\
\hline Growth $42^{\circ} \mathrm{C}$ & + & + & + & + & + & + & + \\
\hline $\begin{array}{l}\text { Growth } 4 \% \\
\quad \mathrm{NaCl}\end{array}$ & + & + & + & + & + & + & + \\
\hline $\begin{array}{l}\text { Growth } 7 \% \\
\quad \mathrm{NaCl}\end{array}$ & - & + & + & + & + & + & + \\
\hline $\begin{array}{l}\text { Growth } 10 \% \\
\quad \mathrm{NaCl}\end{array}$ & - & - & - & + & + & + & - \\
\hline Glucose & + & + & + & + & + & + & + \\
\hline Sucrose & + & - & - & + & - & + & - \\
\hline Fructose & + & - & + & + & + & + & - \\
\hline Maltose & + & - & - & - & - & + & - \\
\hline Galactose & - & - & - & - & - & - & - \\
\hline Xylose & - & + & - & - & - & - & - \\
\hline Rhamnose & - & - & - & - & - & - & + \\
\hline
\end{tabular}


Table 3. PHA production by oxalotrophic strains.

\begin{tabular}{|c|c|c|c|c|c|c|c|}
\hline \multicolumn{8}{|c|}{ Production of PHA (mg/L) } \\
\hline $\begin{array}{c}\text { Time } \\
\text { (hours) }\end{array}$ & OS1 & OS2 & OS3 & OS4 & OT1 & OT2 & OT3 \\
\hline 0 & 0 & 0 & 0 & 0 & 0 & 0 & 0 \\
\hline 24 & 0 & $67.0 \pm 0.08$ & 0 & $33.0 \pm 0.01$ & 0 & 0 & 0 \\
\hline 48 & $30.2 \pm 0.06$ & $133 \pm 0.01$ & 0 & $67.0 \pm 0.01$ & $33.0 \pm 0.04$ & 0 & $33.0 \pm 0.19$ \\
\hline 72 & $33.0 \pm 0.02$ & $200 \pm 0.23$ & 0 & $100 \pm 0.08$ & $67.0 \pm 0.10$ & 0 & $67.0 \pm 0.06$ \\
\hline 96 & $30.0 \pm 0.04$ & $233 \pm 0.15$ & $167 \pm 0.01$ & $100 \pm 0.02$ & $133 \pm 0.61$ & $33.0 \pm 0.20$ & $100 \pm 0.14$ \\
\hline 120 & $67.0 \pm 0.01$ & $67.0 \pm 0.10$ & $100 \pm 0.02$ & $100 \pm 0.13$ & $149 \pm 0.02$ & $33.0 \pm 0.07$ & $67.0 \pm 0.44$ \\
\hline 144 & $126 \pm 0.17$ & $14.0 \pm 0.31$ & $51.0 \pm 0.22$ & $118 \pm 0.44$ & 30.0 & $29.0 \pm 0.61$ & $74.0 \pm 0.06$ \\
\hline
\end{tabular}

The two genera found in this study have been previously reported as oxalotrophic bacteria. Serratia marcescens WW4 (L7ZNH5), S. liquefaciens ATCC 27592 (S5EPA6), S. proteamaculans 568 (A8GE83), S. nematodiphila (A0A086GF10) and S.grimesii (A0A084YYH3) all have an oxalate decarboxylase gene that is necessary to catalyse oxalate. Some species of the Bacillus genus are reported to have oxalate-metabolizing activity in soil from the sagebrush steppe [46] and in tropical soils [14]. The ecological role of this genus is important because bacteria of this genus have been isolated from rhizospheric soil of different regions [5,47]. It is known that Serratia quinovorans and S. liquefaciens provide substances for plant growth and help with nitrogen fixation $[47,48]$. In addition, these bacteria have antifungal properties and act as insect pathogens; this would probably explain why the presence of fungi was not observed in our study. Moreover, it has been shown that Bacillus strains produce substances that promote plant growth, including gibberellins, indole acetic acid [49], and enzymes that act on phytic acid (phytases) [50].

Oxalotrophic bacteria can be 'generalists', i.e., when they can metabolize other substrates, or 'specialists', i.e., when they use oxalate as the sole carbon and energy source $[51,52]$. The bacteria in this study are generalists because they can metabolize oxalate and other compounds such as glucose. Therefore, these bacteria can be improved for future applications (such as ecological and clinical applications and the production of pharmaceuticals (e.g., anti-stress agents, antioxidants, and immune stimulants) from fruit extracts) because they can produce PHA from oxalate or glucose $[12,14,26,52]$. 
The identified oxalotrophic bacteria produced PHA. Serratia fonticola exhibited accumulation of $\mathrm{P}(3 \mathrm{HB})$, coinciding with a report [51]. Bacillus vallismortis, B. amyloliquefaciens, and $B$. cereus produce $\mathrm{P}(3 \mathrm{HB})$, and $B$. subtilis produces the copolymer $\mathrm{P}(3 \mathrm{HB}-\mathrm{co}-3 \mathrm{HV})$. The Bacillus genus shows rapid growth, and the hydrolytic enzymes of this genus produce structural copolymers from countless sources of carbon [53,54]. These strains have potential for future use because there is extensive information about Bacillus PHA producers, with PHA yields ranging mainly from $11 \%$ to $69 \%$. Meanwhile, given the characteristics and potential applications of these organisms, there are different favourable PHA products with a wide range of monomer compositions: $\mathrm{PHB}, \mathrm{P}(3 \mathrm{HBco}-3 \mathrm{HV}), \mathrm{P}(3 \mathrm{HB}-\mathrm{co}-3 \mathrm{HHx})$, $\mathrm{P}(3 \mathrm{HB}-$-co-4HB-co-3HHx), $\mathrm{P}(3 \mathrm{HB}-$-co-6HHx-co-3HHx), $\mathrm{P}(3 \mathrm{HB}-\mathrm{co}-4 \mathrm{HB})$, and $\mathrm{P}(3 \mathrm{HB}-\mathrm{co}-3 \mathrm{HV}-\mathrm{co}-4 \mathrm{HB})$. The formation of these products depends on the substrate and the fermentation conditions [55-60]. The system can be optimized to produce good yields of the copolymer for industrial applications of PHA.

The PHA observed in these strains is an alternative carbon source when the oxalate is completely transformed into carbonate and calcium ions. The oxido-reduction of oxalate-carbonate occurs biochemically via bacterial activity [61]. The energy produced by oxalate forces the microbial metabolism to perform other functions such as regulating the redox potential of the cell and decreasing oxygen concentrations; this allows for a concurrent increase in cellular levels of NADP [62]. Oxalate requires a high activation energy, but the energy efficiency is quite high for catabolic metabolism $(-328 \mathrm{~kJ} / \mathrm{e}-$ pair [26] compared to a glucose yield of $-287.3 \mathrm{~kJ} / \mathrm{e}-$ pair [63]) because one mole of oxalate can yield two ATPs; the Krebs cycle via glycerate/succinate is reactivated. Oxalate is a carbon and energy source, and the synthesis of PHA can likely occur via assimilation of oxalate with other carbohydrate sources, such as glucose. It is thought that the glycolate or serine pathway form the 3 P-glycerate [5]; these are substances considered precursors of acetyl-CoA, which is a metabolic molecule that yields PHB [22]. Various factors are involved in the formation of PHA. It would be interesting to propose a biosynthetic pathway based on experimental knowledge of the oxalate-carbonate pathway.

In this study, seven PHA-producing bacteria are reported. Six of these bacteria belong to the genus Bacillus (B. subtilis with two strains; B. vallismortis with two strains; $B$. amyloliquefaciens with one strain; and B. cereus with one strain) and one belongs to the genus Serratia (S. fonticola). PHA production on an industrial scale is mostly conducted with gram-negative bacteria, such as Ralstonia eutropha and recombinant Escherichia coli, 
because these bacteria grow rapidly and allow a high accumulation of biopolymers; however, these bacteria contain endotoxins that generate a strong immunogenic reaction in humans. Therefore, the application of PHA obtained from gram-negative bacteria is mainly restricted to the biomedical field. Additionally, gram-negative bacteria require expensive substrates such as propionic acid and valeric acid for the synthesis of biopolymers. In this sense, gram-positive bacteria such as those reported in this study have potential for application because they do not produce endotoxins and can also use inexpensive substrates or waste substances and transform them into polymers of interest, such as PHA, significantly lowering the cost of obtaining the polymer $[64,65]$. In this regard, it is worth mentioning that strains of the genus Bacillus grow very fast and in a wide variety of substrates [65].

The bioprospection of PHA in different environments is important. The future applications of the PHA polymers are mostly dependent on the challenge of increasing the production levels to obtain polymers with desired properties in an economical fashion. PHAs have been shown to be good candidates for tissue engineering applications, included in biomedical devices and as controlled drug carriers; agricultural applications; and protein purification applications, as well as candidates for use as biofuels [66-68]. For applications of PHA, the current technology - the whole process from the beginning to the final step- needs improvement. This suggests the selection and development of bacterial strains that are capable of efficient consumption and transformation of various substrates into a range of PHAs with different properties at a high yield, with high productivity using high-performance fermentations and efficient extraction and purification methods to lower the price. The utilization of cheap, locally available substrates, such as agri-waste, and cultivation processes combining batch and fed-batch fermentations may result in the highest productivity compared to other reported methods. However, considering the controllable nature of chemostats, these bioreactors have the greatest potential to provide higher productivities. Therefore, several current research efforts are devoted to lowering the production cost and meeting the target pricing by developing more efficient fermentation routes and recovery processes using recombinant or wild-type organisms. This field of research requires further investigation to enhance productivity and lower production costs rendering the product more competitive. All efforts at the laboratory scale will need to be validated at a pilot scale for future industrial production. The challenges of scaling up might hinder the use of procedures and processes that have been proposed as promising. Therefore, it is expected that ongoing research worldwide will soon potentially lead to PHA production at an acceptable cost $[29,65,69,70,71]$. 


\section{conclusions}

The identified bacteria were: Serratia fonticola, Bacillus amyloliquefaciens, Bacillus subtilis, Bacillus vallismortis, and Bacillus cereus. Increased oxalate capacity and the carbon storage mechanism are new characteristics that contribute to the understanding of the oxalate-carbonate pathway.

The identified species play an important role in the soil of Oxalis plants, as reported in previous studies. These bacteria are promoters of plant growth and exhibit high rates of oxalate degradation, and may be considered as potentially useful in acidic soils as an alternative to bioremediation processes.

The high capacity for oxalate bioconversion using carbon reserve mechanisms for the synthesis of biopolymers by the microbial community studied was confirmed.

Given the versatility of the bacterial metabolism, such as oxalotrophy, and the versatility of PHA polymers, there are various potential applications, and the demand for PHA-based devices will continue to grow especially given the continued research in environmental and medical applications.

\section{Acknowledgements}

We thank Maira Quiroz and Vanessa Pérez for their help with the experimental procedures. This research was supported by the research division (VIPRI) of the Universidad de Nariño, Colombia.

\section{Conflict of interest}

The authors declare that there are no conflicts of interest.

\section{References}

[1] Pendall E, Bridgham S, Hanson PJ, Hungate B, Kicklighter DW, Johnson DW, et al. Below-ground process responses to elevated $\mathrm{CO}_{2}$ and temperature: A discussion of observations, measurement methods, and models, New Phytologist, 162(2): 311-322, 2004.

doi: 10.1111/j.1469-8137.2004.01053.x

[2] Suter D, Frehner M, Fischer BU, Nösberger J, Lüscher A. Elevated $\mathrm{CO}_{2}$ increases carbon allocation to the roots of Lolium perenne under free-air $\mathrm{CO}_{2}$ enrichment but not in a controlled environment, New Phytologist, 154(1): 65-75, 2002.

doi: 10.1046/j.1469-8137.2002.00368.x 
[3] Haase S, Neumann G, Kania A, Kuzyakov Y, Römheld V, Kandeler E. Elevation of atmospheric $\mathrm{CO}_{2}$ and $\mathrm{N}$-nutritional status modify nodulation, nodule-carbon supply, and root exudation of Phaseolus vulgaris L, Soil Biology \& Biochemistry, 39(9): 2208-2221, 2007.

doi: 10.1016/j.soilbio.2007.03.014

[4] Luo Y, Weng E. Dynamic disequilibrium of the terrestrial carbon cycle under global change, Trends in Ecology and Evolution, 26(2): 96-104, 2011. doi: 10.1016/j.tree.2010.11.003

[5] Sahin N. Oxalotrophic bacteria, Research in Microbiology, 154: 399-407, 2003. doi: 10.1016/S0923-2508(03)00112-8

[6] Franceschi VR, Nakata PA. Calcium oxalate in plants: formation and function, Annual Review of Plant Biology, 56: 41-71, 2005.

doi: 10.1146/annurev.arplant.56.032604.144106

[7] Yang JC, Loewus FA. Metabolic Conversion of 1-Ascorbic Acid to Oxalic Acid in Oxalate-accumulating Plants, Plant Physiology, 56(2): 283-285, 1975.

doi: $10.1104 /$ pp. 56.2 .283

[8] Albihn PBE, Savage GP. The bioavailability of oxalate from Oca (Oxalis tuberosa), Journal of Urology, 166(2): 420-422, 2001.

doi: 10.1016/S0022-5347(05)65956-3

[9] Lima VLAG, Mélo EDA, Santos Lima LD. Physicochemical characteristics of bilimbi (Averrboa bilimbi L.), Revista Brasileira de Fruticultura, 23(2): 421-423, 2001.

doi: 10.1590/S0100-29452001000200045

[10] Dubois M, Savage GP, Martin RJ. The effect of cooking on the composition and colour of New Zealand grown oca, Food Chemistry, 104(2): 768-73, 2007.

doi: 10.1016/j.foodchem.2006.12.022

[11] Türkmen N. Oxalis Pes-Caprae F. Pleniflora (Lowe) Sunding (Oxalidaceae), A New Record for the Flora of Turkey, American-Eurasian Journal of Agricultural and Environmental Science, 7(5): 596-599, 2010.

[12] Martin G, Guggiari M, Bravo D, Zopfi J, Cailleau G, Aragno M, et al. Fungi, bacteria and soil $\mathrm{pH}$ : The oxalate-carbonate pathway as a model for metabolic interaction, Environmental Microbiology, 14(11): 2960-2970, 2012.

doi: 10.1111/j.1462-2920.2012.02862.x 
[13] Braissant O, Verrecchia EP, Aragno M. Is the contribution of bacteria to terrestrial carbon budget greatly underestimated? Naturwissenschaften, 89(8): 366-370, 2002.

doi: 10.1007/s00114-002-0340-0

[14] Bravo D, Braissant O, Cailleau G, Verrecchia E, Junier P. Isolation and characterization of oxalotrophic bacteria from tropical soils, Archives of Microbiology, 197(1): 65-77, 2014.

doi: 10.1007/s00203-014-1055-2

[15] Driessens FCM, Verbeeck RMH. Biominerals. CRC Press, Florida, United States, 312-313, 1990.

[16] Chutipongtanate S, Sutthimethakorn S, Chiangjong W, Thongboonkerd $\mathrm{V}$. Bacteria can promote calcium oxalate crystal growth and aggregation. Journal of Biological Inorganic Chemistry, 18: 299-308, 2013

doi: 10.1007/s00775-012-0974-0

[17] Aragno M, Verrecchia E. The Oxalate-Carbonate Pathway: A Reliable Sink for Atmospheric $\mathrm{CO}_{2}$ through Calcium Carbonate Biomineralization in Ferralitic Tropical Soils. Satyanarayana T, Johri BN, Prakash A. (Ed.). Microorganisms in Environmental Management. Microbes and Environment. Springer, New York, United States, 191-200, 2012.

doi: 10.1007/978-94-007-2229-3

[18] Dhami NK, Reddy MS, Mukherjee A. Biomineralization of calcium carbonates and their engineered applications: a review. Frontiers in Microbiology, 4: 314.

doi: $10.3389 /$ fmicb.2013.00314

[19] Braissant O, Cailleau G, Aragno M, Verrecchia EP. Biologically induced mineralization in the tree Milicia excels (Moraceae): its causes and consequences to the environment. Geobiology, 2(1): 59-66, 2004.

doi: 10.1111/j.1472-4677.2004.00019.x

[20] Kim BS, Lee SC, Lee SY, Chang HN, Chang YK, Woo SI. Production of poly (3-hydroxybutyric-co-3-hydroxyvaleric acid) by fed-batch culture of Alcaligenes eutrophus with substrate control using on-line glucose analyzer, Enzyme and Microbial Technology, 16(7): 556-561, 1994.

doi: 10.1016/0141-0229(94)90118-X

[21] Steinbüchel A. Perspectives for Biotechnological Production and Utilization of Biopolymers: Metabolic Engineering of Polyhydroxyalkanoate Biosynthesis Pathways as a Successful Example, Macromolecular Bioscience, 1(1): 1-24, 2001.

doi: 10.1002/1616-5195(200101)1:1<1::AID-MABI1>3.0.CO;2-B 
[22] Korotkova N, Chistoserdova L, Lidstrom ME. Poly- $\beta$-hydroxybutyrate biosynthesis in the facultative methylotroph Metbylobacterium extorquens AM1: Identification and mutation of gap11, gap20, and phaR, Journal of Bacteriology, 184(22): 6174-6181, 2002.

doi: 10.1128/JB.184.22.6174-6181.2002

[23] Somasegaran P, Hoben H.J. Handbook for rhizobia: methods in Legume-rhizobium technology. Springer-Verlag New York, Inc. 1-500, 1994.

doi: 10.1007/978-1-4613-8375-8

[24] Castillo-Arteaga RD, EM Burbano-Rosero EM, ID Otero-Ramirez ID, Fernández-Izquierdo P. Degradación de oxalato por bacterias oxalotróficas asociadas a plantas del género Oxalis sp en regiones Andinas del departamento de Nariño, Colombia, Universidad y Salud, 8(1):69-78, 2016.

[25] Aragno M. Thermophilic, Aerobic, Hydrogen-Oxidizing (Knallgas) Bacteria. The Prokaryotes: a handbook on the biology of bacteria: ecophysiology, isolation, identification, applications. Balows A, Trüper HG, Dworkin M, Harder W, Schleifer KH (eds) Springer, New York, NY. 17: 3917-3933, 1992.

doi: 10.1007/978-1-4757-2191-1

[26] Bravo D, Braissant O, Solokhina A, Clerc M, Daniels AU, Verrecchia $\mathrm{E}$, et al. Use of an isothermal microcalorimetry assay to characterize microbial oxalotrophic activity, FEMS Microbiology Ecology, 78(2): 266-274, 2011.

doi: 10.1111/j.1574-6941.2011.01158.x

[27] Spiekermann P, Rehm BHA, KalscheuerR, Baumeister D, Steinbüchel A. A sensitive, viable-colony staining method using Nile red for direct screening of bacteria that accumulate polyhydroxyalkanoic acids and other lipid storage compounds, Archives of Microbiology, 171(2): 73-80, 1999.

doi: $10.1007 /$ s002030050681

[28] Sahin N, Gökler I, Tamer, AÜ, 2002. Isolation, characterization and numerical taxonomy of novel oxalate-oxidizing bacteria, Journal of Microbiology, 40: 109-118.

[29] Brigham JB, Sinskey JS. Applications of Polyhydroxyalkanoates in the Medical Industry, International Journal of Biotechnology for Wellness Industries, 1: 53-60, 2012.

doi: 10.6000/1927-3037.2012.01.01.03 
[30] Braissant O. Carbonatogénèse bactérienne liée au cycle biogéochimique oxalate-carbonate. Doctoral these, Université de Neuchâtel, Institut de biologie, Faculte des Sciences, Neuchâtel, Swiss, 2005

[31] Spiekermann P, Rehm BHA, Kalscheuer R, BaumeisterD, Steinbüchel A. A sensitive, viable-colony staining method using nile red for direct screening of bacteria that accumulate polyhydroxyalkanoic acids and other lipid storage compounds, Archives of Microbiology, 171(2): 73-80, 1999.

doi: $10.1007 / \mathrm{s} 002030050681$

[32] Kranz R, Gabbert K, Madigan MT. Positive selection systems for discovery of novel polyester biosynthesis genes based on fatty acid detoxification, Applied and Environmental Microbiology, 63(8): 3010-3013, 1997.

[33] Blackmore MA, Quayle JR. Choice between autotrophy and heterotrophy in Pseudomonas oxalaticus. Growth in mixed substrates, Biochemical Journal, 107(5): 705-713. 1968.

[34] Rocha RCS, Da Silva LF, Taciro MK, Pradella JGC. Production of poly(3-hydroxybutyrate-co-3-hydroxyvalerate) $\mathrm{P}(3 \mathrm{HB}-\mathrm{co}-3 \mathrm{HV})$ with a broad range of $3 \mathrm{HV}$ content at high yields by Burkholderia sacchari IPT 189, World Journal of Microbiology and Biotechnology, 24(3): 427-31, 2008.

doi: $10.1007 /$ s11274-007-9480-x

[35] Otero-Ramírez ID, Fernández I. P. Bioprospección de bacterias productoras de Polihidroxialcanoatos (PHA's) en el departamento de Nariño, Biotecnología en el sector agropecuario y agroindustrial, 11(spe): 12-20, 2013.

[36] Fernández P, Ortíz F. Influencia de fuentes de carbono y nitrógeno en el crecimiento bacteriano y en la síntesis de copolímero Poli-(hidroxibutirato-co-hidroxivalerato) de una cepa silvestre de Bacillus mycoides, Universidad y Salud, 1: 34-42, 2006.

[37] Breed RS, Murray EGD, Smith NR, Allen ON, Andrewes CH. Barker HA, et.al. Bergey's manual of determinative Bacteriology, 7th Ed. Waverly Press, Inc, Baltimore, U. S. A. 1: 1-1881, 1957.

[38] Rivera IN, Lipp EK, Gil A, Choopun N, Huq A, Colwell RR. Method of DNA extraction and application of multiplex polymerase chain reaction to detect toxigenic Vibrio cholerae O1 and O139 from aquatic ecosystems, Environmental Microbiology, 5(7): 599-606, 2003.

doi: 10.1046/j.1462-2920.2003.00443.x 
[39] Sambrook J, Fritch EF, Maniatis T. Molecular Cloning: A Laboratory Manual. 2nd Ed. Cold Spring Harbor Laboratory Press, Cold Spring Harbor, New York, United States, 1: 10-22, 1989.

[40] Lane D. 16S/23S rRNA sequencing. In: Stackebrandt, E. Oodfellow, M. (Ed.). Nucleic acid techniques in bacterial systematics. John Wiley \& Sons, Chichester, England, 115-163. 1991.

[41] Nubel U, Engelen B, Felske A, Snaidr J, Wieshuber A, Amann R, Ludwig W, Backhaus H. Sequence Heterogeneities of Genes Encoding 16S rRNAs in Paenibacilluspolymyxa Detected by Temperature Gradient Gel Electrophoresis, Journal of Bacteriology, 178(19): 5636-5643, 1996.

doi: $10.1128 /$ jb.178.19.5636-5643.1996

[42] Sanger F, Nicklen S, Coulson AR. DNA sequencing with chainterminating inhibitors. Proceedings of the National Academy of Sciences, 74(12): 5463-5467, 1977

[43] Cole JR, Wang Q, Cardenas E, Fish J, Chai B, Farris RJ, et al. The Ribosomal Database Project: Improved alignments and new tools for rRNA analysis, Nucleic Acids Research, 37(Database issue): D141-D145, 2009.

doi: $10.1093 /$ nar/gkn879

[44] Herve V, Junier T, Bindschedler S, Verrecchia E, Junier P. Diversity and ecology of oxalotrophic bacteria, World Journal of Microbiology and Biotechnology, 32: 28, 2016.

doi: $10.1007 /$ s11274-015-1982-3

[45] Cailleau G, Mota M, Bindschedler S, Junier P, Verrecchia EP. Detection of active oxalate-carbonate pathway ecosystems in the Amazon Basin: Global implications of a natural potential C sink, Catena, 116: 132-141, 2014.

doi: 10.1016/j.catena.2013.12.017

[46] Morris SJ, Allen MF. Oxalate-metabolizing microorganisms in sagebrush steppe soil, Biology and Fertility of Soils, 18(3): 255-259, 1994.

doi: $10.1007 / \mathrm{BF} 00647677$

[47] Ashelford KE, Fry JC, Bailey MJ, Day MJ. Characterization of Serratia isolates from soil, ecological implications and transfer of Serratia proteamaculans subsp. quinovora Grimont et al. 1983 to Serratia quinivorans corrig., sp. nov. International Journal of Systematic and Evolutionary Microbiology. 52(6): 2281-2289, 2002.

doi: 10.1099/ijs.0.02263-0 
[48] Grimont PAD, Grimont F, Starr MP. Serratia species isolated from plants, Current Microbiology, 5(5): 317-322, 1981.

doi: 10.1007/BF01567926

[49] Turner JT, Backman PA. Factors relating to peanut yield increases after seed treatment with Bacillus subtilis, Plant Disease, 75(4): 347-353, 1991.

[50] Idriss EE, Makarewicz O, Farouk A, Rosner K, Greiner R, Bochow $\mathrm{H}$, et al. Extracellular phytase activity of Bacillus amyloliquefaciens FZB45 contributes to its plant-growth-promoting effect, Microbiology, 148(7): 2097-2109, 2002.

doi: 10.1099/00221287-148-7-2097

[51] Lugg H, Sammons RL, Marquis PM, Hewitt CJ, Yong P, PatersonBeedle M, et al. Polyhydroxybutyrate accumulation by a Serratia sp. Biotechnology Letters, 30(3): 481-491, 2008.

doi: 10.1007/s10529-007-9561-9

[52] Trinchant J-C, Rigaud J. Bacteroid oxalate oxidase and soluble oxalate in nodules of Faba bean (Vicia faba L.) submitted to water restricted conditions: possible involvement in nitrogen fixation, Journal of Experimental Botany, 47(305): 1865-1870. 1996.

[53] Halami PM. Production of polyhydroxyalkanoate from starch by the native isolate Bacillus cereus CFR06, World Journal of Microbiology and Biotechnology, 24(6): 805-812, 2008.

doi: $10.1007 /$ s11274-007-9543-z

[54] Valappil SP, Peiris D, Langley GJ, Herniman JM, Boccaccini AR, Bucke C, et al. Polyhydroxyalkanoate (PHA) biosynthesis from structurally unrelated carbon sources by a newly characterized Bacillus spp. Journal of Biotechnology. 127(3): 475-487, 2007.

doi: 10.1016/j.jbiotec.2006.07.015

[55] Wu Q, Huang H, Hu G, Chen J, Ho KP, Chen GQ. Production of poly-3-hydroxybutrate by Bacillus sp. JMa5 cultivated in molasses media, Antonie van Leeuwenhoek, 80(2): 111-118, 2001.

doi: 10.1023/A:1012222625201

[56] Bordoloi M, Borah B, Thakur PS, Nigam JN. Process for the isolation of polyhydroxybutyrate from Bacillus mycoides RLJ B-017. U.S. Patent 7273733, 2007. 
[57] Katırcıŏlu H, Aslim B, Yüksekdað ZN, Mercan N, Beyatlı Y. Production of poly- $\beta$-hydroxybutyrate (PHB) and differentiation of putative Bacillus mutants strains by SDS-PAGE of total cell protein, African Journal of Biotechnology, 2(6): 147-149, 2003.

doi: 10.4314\%2Fajb.v2i6.14788

[58] Porwal S, Kumar T, Lal S, Rani A, Kumar S, Cheema S, et al. Hydrogen and polyhydroxybutyrate producing abilities of microbes from diverse habitats by dark fermentative process, Bioresource Technology, 99(13): 5444-5451, 2008.

doi: 10.1016/j.biortech.2007.11.011

[59] Singh M, Patel SK, Kalia VC. Bacillus subtilis as potential producer for polyhydroxyalkanoates, Microbial Cell Factories, 8: 38, 2009.

doi: 10.1186/1475-2859-8-38

[60] Aarthi N, Ramana K V. Identification and Characterization of Polyhydroxybutyrate producing Bacillus cereus and Bacillus mycoides strains, International Journal of Environmental Sciences. 1(5): 744-756, 2011.

[61] Verrecchia EP, Braissant O, Cailleau G. The oxalate-carbonate pathway in soil carbon storage: the role of fungi and oxalotrophic bacteria. Fungi in Biogeochemical Cycles, Cambridge University Press, G.M. Gadd Editors, Chapter 12: 289-310, 2006.

doi: 10.1017/CBO9780511550522.013

[62] Trainer MA, Charles TC. The role of PHB metabolism in the symbiosis of rhizobia with legumes, Applied Microbiology and Biotechnology. 71(4): 377-386, 2006.

doi: 10.1007/s00253-006-0354-1

[63] Schaarschmidt B, Lamprecht I. Calorimetric characterization of microorganisms. Experientia. 32(10), 1230-1234, 1976.

doi: 10.1007/BF01953065

[64] López J, Naranjo M, Higuita J, Cubitto M, Cardona C, Villar M. Biosynthesis of PHB from a new isolated Bacillus megaterium strain outlook on future developments with endospore forming bacteria, Biotechnology and bioprocess engineering, 17(2): 250-258, 2012.

doi: 10.1007/s12257-011-0448-1

[65] Mizuno K, Ohta A, Hyakutake M, Ichinomiya Y, Tsuge T. 2010 Isolation of polyhydroxyalkanoate producing bacteria from a polluted soil and characterization of the isolated strain Bacillus cereus YB-4, Polymer degradation and stability, 95: 1335-1339.

doi: 10.1016/j.polymdegradstab.2010.01.033 
[66] Grande D, Ramier J, Versace DL, Renard E, Langlois V. Design of Functionalized Biodegradable PHA- Based Electrospun Scaffolds Meant for Tissue Engineering Applications, New Biotechnology, 37(Pt A): 129-137, 2017.

doi: 10.1016/j.nbt.2016.05.006

[67] Chee JY, Yoga SS, Lau NS, Ling SC, Abed RMM, Sudesh K. Bacterially Produced Polyhydroxyalkanoate (PHA): Converting Renewable Resources into Bioplastics. Current Research Technology and Education Topics in Applied Microbiology and Microbial Biotechnology, Mendez-Vilas A Editor, Formatex Research Center, Badajoz, Spain, 2: 1395-1404, 2010.

[68] Lam W, Wang Y, Chan PL, Chan SW, Tsang YF, Chua H, et al. Production of polyhydroxyalkanoates (PHA) using sludge from different wastewater treatment processes and the potential for medical and pharmaceutical applications. Environmental Technology, 38(13-14): 1779-1791, 2017.

doi: 10.1080/09593330.2017.1316316

[69] Muhammadi, Shabina, Afzal M, Hameed S. Bacterial polyhydroxyalkanoates-eco-friendly next generation plastic: Production, biocompatibility, biodegradation, physical properties and applications, Green Chemistry Letters and Reviews, 8(3-4): 56-77, 2015.

doi: 10.1080/17518253.2015.1109715

[70] Shivakumar S. Accumulation of poly (3hydroxybutyrate) by Microbacterium barkeri DSM 20145, Turkish Journal of Biology, 36: 225-232, 2012.

[71] Paladino LPA. Screening, optimization and extraction of polyhydroxyalkanoates and peptidoglycan from Bacillus megaterium. Master's report, Michigan Technological University, Houghton, United States, 2009. 


\section{Biosíntesis de polihidrxialcanoato por bacterias oxalotróficas de suelos altoandinos}

Resumen. El oxalato es un anión de ácido orgánico altamente oxidado usado como fuente carbono y energía por bacterias oxalotróficas. Las plantas oxalogénicas convierten $\mathrm{CO}_{2}$ atmosférico en ácido oxálico y sales oxálicas. La formación de sales de oxalato actúa como un sumidero de carbono en ecosistemas terrestres via oxalato-carbonato (OCP). Las bacterias oxalotróficas podrían estar implicadas en otros procesos de almacenamiento de carbono, incluyendo la síntesis de polihidroxialcanoatos (PHAs). Recientemente, una variedad de bacterias de la región andina colombiana en Nariño ha sido reportada por su habilidad para producir PHAs. Estas especies pueden degradar oxalato y participar en la vía del oxalato-carbonato. El objetivo de este estudio fue aislar y caracterizar bacterias oxalotróficas con capacidad de acumular biopolímeros PHA. Se colectaron plantas del genero Oxalis y se aislaron bacterias del suelo adheridas a las raíces. Las cepas bacterianas aisladas se caracterizaron usando métodos bioquímicos y de biología molecular. Se cuantificó el consumo de oxalato en cultivo, y se monitoreó la producción de PHA en fermentación por lotes. La composición polimérica se caracterizó usando cromatografía de gases. Finalmente, se propone una via biosintética basada en nuestros hallazgos y en los de otras fuentes publicadas. Se encontró que las cepas de Bacillus spp. y Serratia sp. metabolizan oxalato de calcio y sintetizan PHA.

Palabras clave: bacterias oxalotróficas; polihidroxialcanoatos; gen $16 \mathrm{~S}$ rRNA; cromatografía de gases; vía biosintética in silicos

\section{Biossínteses de polihidroxialcanoato por bactérias oxalotróficas de solos andinos}

Resumo. O oxalato é um ânion de ácido orgânico altamente oxidado utilizado como fonte de carbono e nergía por bactérias oxalotróficas. As plantas oxalogênicas convertem $\mathrm{CO}_{2}$ atmosférico em ácido oxálico e sais oxálicos. A formação de sais de oxalato atua como um sumidouro de carbono em ecossistemas terrestres via oxalato-carbono (OCP). As bactérias oxalotróficas poderiam estar envolvidas em outros processos de armazenamento de carbono, incluindo a sínteses de polihidroxialcanoatos (PHAs). Recentemente, uma variedade de bactérias da região Andina colombiana no Departamento de Nariño foi reportada devido a sua habilidade para produzir PHAs. Estas espécies podem degradar oxalato e participar na via oxalato-carbono. O objetivo de esse estudo foi isolar e caracterizar bactérias oxalotróficas com capacidade de acumular biopolímeros PHA. Plantas do género Oxalis foram coletadas e se isolaram bactérias do solo aderido a suas raízes. As cepas bacterianas isoladas se caracterizaram utilizando métodos bioquímicos e de biologia molecular. O consumo de oxalato em cultivo foi quantificado, e a produção de PHA foi monitorada em fermentação por lotes. A composição polimérica se caracterizou utilizando Cromatografia de Gases. Finalmente, se propõe uma via biossintética baseada em nossos resultados juntamente com resultados da literatura. Se encontrou que as cepas de Bacillus spp. e Serratia sp. metabolizam oxalato de cálcio e sintetizam PHA.

Palavras-chave: Bactérias oxalotróficas; polihidroxialcanoatos; gen $16 \mathrm{~S}$ rRNA; Cromatografia de Gases; via biossintética in sílico 


\section{Roger David Castillo Arteaga}

Biologist, Master in Microbiology (University of São Paulo). Currently doctoral student in Pharmaceutical Biology at the University of Tübingen, Germany.

\section{Edith Mariela Burbano Rosero}

Biologist, Master in Microbiology (Pontificia Universidad Javeriana), Doctor in Science (University of São Paulo). Currently research Professor at the University of Nariño, Colombia.

\section{Iván Darío Otero Ramírez}

Biologist. Master in Agroindustrial Microbiology. Professor at the Universidad del Cauca Colombia. Researcher in bioprospecting microorganisms, polyhydroxyalkanoates-type polymers and develop of microbial probiotics for fish.

\section{Juan Camilo Roncallo}

Industrial Microbiologist (Pontificia Universidad Javeriana), Master of Science (University of São Paulo). Currently researcher in the health area, particularly diagnosis by molecular tests.

\section{Sandra Patricia Hidalgo Bonilla}

Chemist (University of Valle), Master and doctoral degree in Science (National Autonomous University of Mexico. Currently research assistant Professor in chemistry at Yachay Tech University (Ecuador). 
Pablo Fernández Izquierdo

Doctor in Science (Universidad de la Havana). Professor and director of microbial biotechnology group at the University of Nariño, Colombia. 